\title{
Estimation of Heterosis for Yield and Yield Components in Brinjal (Solanum melongena L.) Over Locations
}

\author{
V. Sivakumar ${ }^{1 *}$, K. Uma Jyothi ${ }^{2}$, C. Venkataramana ${ }^{3}$ and R. Rajyalakshmi ${ }^{4}$ \\ ${ }^{1}$ HRS, Dr. YSR Horticultural University, Chintapalli, Visakhapatnam, A.P., Pin-531111, India \\ ${ }^{2}$ Horticulture College, Dr. YSR Horticultural University, Tadepalligudem, \\ West Godavari, A.P., Pin-534101, India \\ ${ }^{3}$ HRS, Dr. YSR Horticultural University, Lam Farm, Guntur, A.P., India \\ ${ }^{4}$ HRS, Dr. YSR Horticultural University, Nuzvidu, Krishna, A.P., India \\ *Corresponding author
}

\begin{tabular}{|c|c|}
\hline & A B S T R A C T \\
\hline & \multirow{6}{*}{$\begin{array}{l}\text { Twenty one crosses resulting from } \mathrm{L} \text { x } \mathrm{T} \text { mating design comprising of } \\
\text { seven lines and three testers were studied to know the magnitude of } \\
\text { heterosis over mid parent, better parent and a commercial check, Ravaiyya. } \\
\text { The parents and the hybrids were evaluated during summer season, } 2014 \text {. } \\
\text { Among the } 21 \text { hybrids, nineteen, fifteen and eleven hybrids exhibited } \\
\text { significantly positive heterosis for fruit yield per plant over mid parent, } \\
\text { better parent and commercial check respectively. The maximum heterosis } \\
\text { for fruit yield per plant was observed in the cross L7 x T1 ( } 92.12 \%) \\
\text { followed by L7 x T3 ( } 90.55 \%) \text { and L7 x T2 ( } 85.74 \%) \text {. The hybrid L7 x T1 } \\
\text { also exhibited highly significant positive heterosis for number of primary } \\
\text { branches per plant, days to 50\% flowering, fruit length and number of fruits } \\
\text { per plant so, these quantitative traits might be contributed to high heterosis } \\
\text { for fruit yield in brinjal. }\end{array}$} \\
\hline Keywords & \\
\hline $\begin{array}{l}\text { Brinjal, Heterosis, } \\
\text { Hybrids, Over } \\
\text { locations and } \\
\text { Yield. }\end{array}$ & \\
\hline Article Info & \\
\hline $\begin{array}{l}\text { Accepted: } \\
\text { 17 June } 2017 \\
\text { Available Online: } \\
\text { 10 July } 2017\end{array}$ & \\
\hline & \\
\hline
\end{tabular}

\section{Introduction}

Brinjal is an important vegetable crop of India and is grown throughout the year. However, it is widely cultivated in both temperate and tropical regions of the globe mainly for its immature fruits as vegetables (Rai et al., 1995), in the temperate regions it is cultivated mainly during warm season. Even though India is regarded as the primary centre of origin/diversity of brinjal (Vavilov, 1931), the productivity of brinjal is very low as compared to other countries such as
In Netherlands the $F_{1}$ hybrids constitute most of the commercial cultivars. The first generation hybrids offer several advantages, such as earliness, uniformity, increased yield and remarkable tolerance to pest and diseases. Heterosis breeding has become the widely used breeding method for increasing productivity of the important Solanaceous vegetable crops including brinjal. Exploitation of hybrid vigour in these crops is commercially possible due to manifestation of 
high heterosis for yield and other important characters, ease of handling the flowers during artificial emasculation and pollination and realization of higher number of hybrid seeds per effective pollination. Though it is a self-pollinated crop, cross pollination is up to the extent of 30 to $40 \%$. In India, only $17.8 \%$ area of brinjal cultivation is under hybrid seed. The scenario of brinjal production in the country has tremendously changed over the past few decades with increasing popularity of hybrids in the commercial cultivation. The growers and consumers are demanding to evolve high yielding varieties/ hybrids with varying qualities as per local demand. Keeping in view, the pace with which the hybrids of brinjal are gaining popularity, it is imperative to obtain such hybrids which have high yielding potential along with excellent quality. Brinjal offers much scope for improvement through heterosis breeding.

\section{Materials and Methods}

The experimental material comprised of ten pure diverse parents including seven lines viz., IC 090053 (L1), IC 285140 (L2), IC 421194 (L3), IC 545893 (L4), IC 90806 (L5), Pusa Shyamala (PS) (L6) and Heera (L7) and three testers namely Bhagyamathi (T1), Gulabi (T2) and Shyamala (T3). Crossings were initiated in Line $\times$ Tester fashion. Each of the seven lines was crossed with three testers during Kharif, 2013-14 to produce 21 hybrids.

The resulting $21 \mathrm{~F}_{1}$ hybrids along with their 10 parents and a commercial check (Ravaiya) were evaluated in a randomized block design with three replications under three diverse environments i.e., at Horticulture College and Research Institute, Venkataramannagudem, Horticulture Research Station, Pandirimamidi and Horticulture Research Station, Aswaraopet for yield and its contributing traits during summer season, 2014. Heterosis for pooled analysis is presented in table 1 $a, b, c$. Each plot consisted of twenty five plants. Inter and intra row spacing was kept 90 and $75 \mathrm{~cm}$, respectively. The observations were recorded on five randomly selected plants from each treatment and replication for nine characters viz., plant height, number of primary branches, days to $50 \%$ flowering, fruit length, fruit girth, average fruit weight, number of fruits per plant, fruit yield per plant and total phenols. Heterosis expressed as per cent increase or decrease in hybrid (F1) over its mid parental value, better parent (BP) and commercial check (CC) values in the desirable direction was calculated using the following formula.

Per cent of
Average heterosis $(\mathrm{AH})=\frac{\overline{\mathrm{F}}-\overline{\mathrm{MP}}}{\overline{\mathrm{MP}}} \times 100$
Mid parent $(\mathrm{MP})$ value $=\frac{\mathrm{P} 1+\mathrm{P} 2}{2}$
Per cent of
Heterobeltiosis $(\mathrm{HB})=-\overline{\mathrm{F}}-\overline{\mathrm{BP}}$
Where,
$\overline{\mathrm{BP}}=$ Mean performance of better parent
$\overline{\text { F }}=$ Mean performance of $\mathrm{F}_{1}$ hybrid
Per cent of
Commercial heterosis $(\mathrm{CC})=\frac{\overline{\mathrm{BP}}-\overline{\mathrm{CC}}}{\overline{\mathrm{CC}}} \times 100$

\section{Results and Discussion}

The magnitude of heterosis over mid parent, better parent (heterobeltiosis) and commercial check for different quantitative characters is depicted in table $1 \mathrm{a}, \mathrm{b}, \mathrm{c}$.

For plant height the crosses were in the range from -15.18 to $18.38 \%$ for average heterosis 
and -18.30 to $7.65 \%$ for heterobeltiosis. The commercial heterosis over Ravaiyya varied from -17.42 to $13.89 \%$. The highest significant positive commercial heterosis over Ravaiyya was recorded by the cross L 3 x T2 (13.89) followed by L5 x T3 (13.80) and significant negative heterosis was observed in L6 x T1 (-17.42).

Twelve crosses showed significant positive heterosis over the check Ravaiyya. Similar findings have been reported by earlier workers, Suneetha et al., (2008) and Makani et al., (2013) in brinjal.

For number of primary branches average heterosis for 21 crosses ranged from -18.47 (L2 $x$ T3) to $15.98 \%$ (L7 x T3), whereas heterobeltiosis ranged from -22.11 (L1 x T1) to $8.57 \%(\mathrm{~L} 7 \mathrm{x} \mathrm{T} 3)$.

The commercial heterosis over Ravaiyya ranged from -20.53 (L2 x T3) to $17.66 \%$ (L7 x T3). Five crosses viz., L5 x T3, L6 x T3, L7 $\mathrm{x}$ T1, L7 x T2 and L7 x T3 showed significant positive commercial heterosis over the check Ravaiyya.

These results are in conformation with the finds of earlier brinjal workers, Rameshkumar et al., (2012) and Reddy and Patli (2014).

Earliness is considered an important character in any crop improvement programme, which is manifested in $F_{1}$ hybrids and preferred for commercial cultivation when the high yield is coupled with earliness. The negative heterosis is considered desirable for days to $50 \%$ flowering.

Most of the hybrids recorded significant negative average heterosis and heterobeltiosis. These results are in agreement with the findings of Das et al., (2009) and Murthy et $a l .$, (2011) in brinjal. All the crosses exhibited positive commercial heterosis over commercial check i.e., no one of the cross recorded earliness for days to $50 \%$ flowering. Fruit length contributes positively to yield. All the crosses recorded significant positive commercial heterosis over Ravaiyya and it ranged from 6.39 to $125.01 \%$. Similar significant positive commercial heterosis was reported by Bhushan et al., (2013) and Reddy and Patil (2014) in brinjal for this trait.

However, it is pertinent to mention here that consumer preference vary greatly for fruit length and shape. Hence a negative commercial heterosis for this trait may not be considered as undesirable.

Fruit girth is another important character as that of fruit length. In the present study both positive and negative average heterosis and heterobeltiosis were recorded. Similar finding were reported by Makani et al., (2013) in brinjal.

However only one cross i.e., L5 x T3 recorded significant commercial heterosis over the check Ravaiyya and the remaining twenty crosses recorded significant negative commercial heterosis. Similar finding were reported by Bhushan et al., (2013) in brinjal.

The magnitude of heterosis for fruit weight ranged from -24.30 (L1 x T1) to $20.46 \%$ (L7 $\mathrm{x}$ T3) over mid parent, -31.65 (L1 x T1) to $4.27 \%$ (L5 x T3) over better parent and 47.21 (L2 x T1) to $11.51 \%$ (L7 x T3) over commercial check.

Significant heterobeltiosis in the desired positive direction was observed by seven hybrids. Two hybrids (L5 x T3 and L7 x T3) exhibited significant positive heterosis over commercial check. The cross L7 x T3 (11.51 $\%)$ showed maximum commercial heterosis (Table 1 a,b,c). Similarly, high magnitude of heterosis was reported by Murthy et al., (2011) and Rameshkumar et al., (2012) in brinjal. 
Int.J.Curr.Microbiol.App.Sci (2017) 6(7): 1074-1081

Table.1a Magnitude of heterosis for different quantitative characters in brinjal

\begin{tabular}{|c|c|c|c|c|c|c|c|c|c|}
\hline \multirow{3}{*}{ Cross } & \multirow{2}{*}{\multicolumn{3}{|c|}{$\begin{array}{l}\text { Plant height } \\
\% \text { Heterosis over }\end{array}$}} & \multirow{2}{*}{\multicolumn{2}{|c|}{$\begin{array}{l}\text { No. of primary branches } \\
\% \text { Heterosis over }\end{array}$}} & \multirow{2}{*}{\multicolumn{4}{|c|}{$\begin{array}{l}\text { Days to } 50 \% \text { flowering } \\
\% \text { Heterosis over }\end{array}$}} \\
\hline & & & & & & & & & \\
\hline & $\begin{array}{l}\text { Mid } \\
\text { parent }\end{array}$ & $\begin{array}{l}\text { Better } \\
\text { parent }\end{array}$ & Ravaiyya & $\begin{array}{l}\text { Mid } \\
\text { parent }\end{array}$ & $\begin{array}{l}\text { Better } \\
\text { parent }\end{array}$ & Ravaiyya & $\begin{array}{l}\text { Mid } \\
\text { parent }\end{array}$ & $\begin{array}{l}\text { Better } \\
\text { parent }\end{array}$ & Ravaiyya \\
\hline L1 x T1 & $3.73^{*}$ & 3.59 & $4.99 *$ & $-17.58 * *$ & $-22.11 * *$ & $-19.32 * *$ & -0.13 & $-5.29 * *$ & $4.51 *$ \\
\hline L1 x T2 & -0.03 & $-5.13 * *$ & $7.08 * *$ & $-8.16 * *$ & $-11.45^{* *}$ & $-8.28 * *$ & $-11.11 * *$ & $-15.99 * *$ & $-6.63 * *$ \\
\hline L1 x T3 & $3.85^{*}$ & 2.81 & 4.20 & $-12.85 * *$ & $-16.65^{* *}$ & $-13.67 * *$ & $13.07 * *$ & $12.47 * *$ & $12.47 * *$ \\
\hline L2 x T1 & -0.46 & $-5.73 * *$ & $6.58 * *$ & $-10.22 * *$ & $-13.89 * *$ & $-13.54 * *$ & $-13.52 * *$ & $-14.66^{* *}$ & $-5.84 * *$ \\
\hline L2 x T2 & $-3.95 *$ & $-4.03 *$ & $8.50 * *$ & $-17.45 * *$ & $-19.19 * *$ & $-18.86 * *$ & -2.43 & $-4.06 *$ & $6.63 * *$ \\
\hline $\mathrm{L} 2 \times \mathrm{T} 3$ & $5.54 * *$ & -0.87 & $12.08 * *$ & $-18.47 * *$ & $-20.85 * *$ & $-20.53 * *$ & -0.51 & $-3.95 *$ & 3.18 \\
\hline L3 x T1 & -7.11 & $-12.19 * *$ & -0.35 & $-14.85 * *$ & $-18.03 * *$ & $-18.33 * *$ & -2.27 & -2.85 & $8.49 * *$ \\
\hline L3 x T2 & 0.63 & 0.36 & $13.89 * *$ & $-6.37 * *$ & $-8.00 * *$ & $-8.34 * *$ & $-4.29 *$ & $-4.51 *$ & $6.63 * *$ \\
\hline L3 x T3 & $4.80^{*}$ & -1.74 & $11.52 * *$ & -2.60 & -5.09 & $-5.44 *$ & 2.26 & -3.09 & $8.22 * *$ \\
\hline L4 x T1 & $18.38 * *$ & $7.65 * *$ & $8.81 * *$ & -1.87 & -3.36 & $-8.10 * *$ & $-5.62 * *$ & $-7.99 * *$ & $6.90 * *$ \\
\hline $\mathrm{L} 4 \times \mathrm{T} 2$ & $3.90^{*}$ & $-9.96 * *$ & 1.62 & -3.74 & -4.27 & $-7.95 * *$ & $-11.32 * *$ & $-13.24 * *$ & 0.80 \\
\hline L4 x T3 & $11.77 * *$ & 2.44 & 1.75 & 2.68 & 2.37 & -2.65 & $-11.41 * *$ & $-17.58 * *$ & $-4.24 *$ \\
\hline L5 x T1 & -1.44 & $-6.91 * *$ & $5.84 * *$ & $-7.53 * *$ & $-11.91 * *$ & $-10.28 * *$ & $-7.92 * *$ & $-9.13 * *$ & 0.27 \\
\hline L5 x T2 & $-4.69 *$ & $-5.04 * *$ & $7.96 * *$ & -2.69 & -5.41 & -3.65 & $-7.04 * *$ & $-8.59 * *$ & 1.59 \\
\hline $\mathrm{L} 5 \times \mathrm{T} 3$ & $6.84 * *$ & 0.09 & $13.80 * *$ & $13.92 * *$ & $9.82 * *$ & $11.86 * *$ & $-5.37 * *$ & $-8.64 * *$ & -1.86 \\
\hline L6 x T1 & $-15.18 * *$ & $-18.30 * *$ & $-17.42 * *$ & $-6.92 * *$ & $-13.43 * *$ & $-7.19 * *$ & $-5.90 * *$ & $-7.93 * *$ & 1.59 \\
\hline L6 x T2 & -1.31 & $-9.72 * *$ & 1.90 & $-6.68 * *$ & $-11.49 * *$ & -5.10 & $-5.02 * *$ & $-7.40 * *$ & 2.92 \\
\hline L6 x T3 & $11.08 * *$ & $7.90 * *$ & $7.17 * *$ & $15.35 * *$ & $8.53 * *$ & $16.36 * *$ & 1.42 & -1.26 & $4.24^{*}$ \\
\hline L7 x T1 & $-7.11 * *$ & $-9.69 * *$ & $-8.72 * *$ & $9.49 * *$ & 1.30 & $9.74 * *$ & $-6.34 * *$ & $-8.49 * *$ & $5.84 * *$ \\
\hline $\mathrm{L} 7 \times \mathrm{T} 2$ & -2.08 & $-9.63 * *$ & 1.99 & $15.01 * *$ & $8.53 * *$ & $17.63 * *$ & $-6.20 * *$ & $-8.03 * *$ & $6.37 * *$ \\
\hline L7 x T3 & -1.24 & -3.16 & -3.81 & $15.98 * *$ & $8.57 * *$ & $17.66^{* *}$ & $-8.73 * *$ & $-14.91 * *$ & -1.59 \\
\hline
\end{tabular}


Int.J.Curr.Microbiol.App.Sci (2017) 6(7): 1074-1081

Table.1b Magnitude of heterosis for different quantitative characters in brinjal

\begin{tabular}{|c|c|c|c|c|c|c|c|c|c|}
\hline \multirow{3}{*}{ Cross } & \multirow{2}{*}{\multicolumn{3}{|c|}{$\begin{array}{l}\text { Fruit length } \\
\% \text { Heterosis over }\end{array}$}} & \multirow{2}{*}{\multicolumn{3}{|c|}{$\begin{array}{l}\text { Fruit girth } \\
\% \text { Heterosis over }\end{array}$}} & \multirow{2}{*}{\multicolumn{3}{|c|}{$\begin{array}{l}\text { Fruit weight } \\
\% \text { Heterosis over }\end{array}$}} \\
\hline & & & & & & & & & \\
\hline & $\begin{array}{l}\text { Mid } \\
\text { parent }\end{array}$ & $\begin{array}{l}\text { Better } \\
\text { parent }\end{array}$ & Ravaiyya & $\begin{array}{l}\text { Mid } \\
\text { parent }\end{array}$ & $\begin{array}{l}\text { Better } \\
\text { parent }\end{array}$ & Ravaiyya & $\begin{array}{l}\text { Mid } \\
\text { parent }\end{array}$ & $\begin{array}{l}\text { Better } \\
\text { parent }\end{array}$ & Ravaiyya \\
\hline L1 x T1 & $-7.73 * *$ & $-10.27 * *$ & $11.56 * *$ & -0.33 & $-5.43 * *$ & $-23.13 * *$ & $-24.30 * *$ & $-31.65 * *$ & $-41.84 * *$ \\
\hline L1 x T2 & $-14.39 * *$ & $-31.45 * *$ & $41.68 * *$ & -1.27 & $-4.78 * *$ & $-30.52 * *$ & $-15.59 * *$ & $-19.94 * *$ & $-31.88 * *$ \\
\hline L1 x T3 & $-3.83^{*}$ & $-11.15 * *$ & $10.46^{* *}$ & $9.16 * *$ & $3.41 *$ & $-15.66^{* *}$ & $-21.62 * *$ & $-26.94 * *$ & $-37.83 * *$ \\
\hline L2 x T1 & $-8.92 * *$ & $-9.44 * *$ & $6.39 * *$ & $-2.96 *$ & $-10.62 * *$ & $-27.34 * *$ & $-11.57 * *$ & $-23.01 * *$ & $-47.21 * *$ \\
\hline L2 x T2 & $8.34 * *$ & $-15.39 * *$ & $74.88 * *$ & $-11.50 * *$ & $-11.93 * *$ & $-39.72 * *$ & $-10.97 * *$ & $-25.84 * *$ & $-43.41 * *$ \\
\hline L2 x T3 & $15.37 * *$ & $10.03 * *$ & $27.80 * *$ & $10.25 * *$ & 1.40 & $-17.30 * *$ & $11.05 * *$ & $-6.11 * *$ & $-30.94 * *$ \\
\hline L3 x T1 & $-4.98 * *$ & $-16.26 * *$ & $28.99 * *$ & -1.82 & $-4.98 * *$ & $-22.76 * *$ & $-18.60 * *$ & $-28.28 * *$ & $-35.47 * *$ \\
\hline L3 x T2 & $-11.78 * *$ & $-23.02 * *$ & $59.11 * *$ & $-7.03 * *$ & $-12.09 * *$ & $-33.14 * *$ & $-12.87 * *$ & $-19.48 * *$ & $-27.56 * *$ \\
\hline L3 x T3 & $-14.69 * *$ & $-28.16 * *$ & $10.66 * *$ & $15.33 * *$ & $11.44 * *$ & $-9.11 * *$ & $3.13 *$ & $-6.28 * *$ & $-15.68 * *$ \\
\hline L4 x T1 & $16.66^{* *}$ & $6.69 * *$ & $25.33 * *$ & $3.78 * *$ & -2.27 & $-10.06 * *$ & 0.09 & $-14.67 * *$ & $-17.01 * *$ \\
\hline $\mathrm{L} 4$ x T2 & $-7.01 * *$ & $-31.60 * *$ & $41.38 * *$ & $15.98 * *$ & 0.70 & $-7.33 * *$ & $9.13 * *$ & -2.63 & $-5.29 *$ \\
\hline L4 x T3 & $10.19 * *$ & $6.00 * *$ & $11.73 * *$ & $8.51 * *$ & 2.34 & $-5.82 * *$ & $6.43 * *$ & $-6.54 * *$ & $-9.10 * *$ \\
\hline L5 x T1 & $10.68 * *$ & 1.97 & $42.17 * *$ & $8.74 * *$ & $5.22 * *$ & $-8.55 * *$ & $20.14 * *$ & 1.36 & 1.10 \\
\hline L5 x T2 & 1.44 & $-15.07 * *$ & $75.54 * *$ & -1.92 & $-12.72 * *$ & $-24.14 * *$ & $-8.03 * *$ & $-18.83 * *$ & $-19.04 * *$ \\
\hline L5 x T3 & $16.64 * *$ & 2.41 & $42.78 * *$ & $23.49 * *$ & $19.69 * *$ & $4.03 *$ & $20.02 * *$ & $4.27^{*}$ & $4.00 *$ \\
\hline L6 x T1 & $34.54 * *$ & $3.68 * *$ & $125.01 * *$ & $-12.11 * *$ & $-17.34 * *$ & $-32.81 * *$ & $16.50 * *$ & -2.47 & -0.84 \\
\hline L6 x T2 & $-3.43 * *$ & $-5.73 * *$ & $104.58 * *$ & $-11.38 * *$ & $-13.76 * *$ & $-38.24 * *$ & $-14.89 * *$ & $-25.51 * *$ & $-24.26 * *$ \\
\hline L6 x T3 & $-17.75 * *$ & $-38.90 * *$ & $32.59 * *$ & $7.29 * *$ & 0.75 & $-17.83^{* *}$ & $-5.39 * *$ & $-18.47 * *$ & $-17.11 * *$ \\
\hline L7 x T1 & $9.93 * *$ & $-14.78 * *$ & $81.88 * *$ & -1.49 & $-5.69 * *$ & $-16.19 * *$ & $8.89 * *$ & $-12.10 * *$ & -1.92 \\
\hline L7 x T2 & $-4.58 * *$ & $-6.10 * *$ & $100.43 * *$ & -1.05 & $-12.79 * *$ & $-22.49 * *$ & 1.75 & $-14.33 * *$ & $-4.41 *$ \\
\hline L7 x T3 & -0.51 & $-25.69 * *$ & $58.61 * *$ & $8.10 * *$ & $3.65 * *$ & $-7.88 * *$ & $20.46 * *$ & -0.06 & $11.51 * *$ \\
\hline
\end{tabular}


Table.1c Magnitude of heterosis for different quantitative characters in brinjal

\begin{tabular}{|c|c|c|c|c|c|c|c|c|c|}
\hline \multirow{3}{*}{ Cross } & \multirow{2}{*}{\multicolumn{3}{|c|}{$\begin{array}{l}\text { No. of fruits per plant } \\
\% \text { Heterosis over }\end{array}$}} & \multirow{2}{*}{\multicolumn{3}{|c|}{$\begin{array}{l}\text { Fruit yield per plant } \\
\% \text { Heterosis over }\end{array}$}} & \multirow{2}{*}{\multicolumn{3}{|c|}{$\begin{array}{l}\text { Total phenols content } \\
\% \text { Heterosis over }\end{array}$}} \\
\hline & & & & & & & & & \\
\hline & $\begin{array}{l}\text { Mid } \\
\text { parent }\end{array}$ & $\begin{array}{l}\text { Better } \\
\text { parent }\end{array}$ & Ravaiyya & $\begin{array}{l}\text { Mid } \\
\text { parent }\end{array}$ & $\begin{array}{l}\text { Better } \\
\text { parent }\end{array}$ & Ravaiyya & $\begin{array}{l}\text { Mid } \\
\text { parent }\end{array}$ & $\begin{array}{l}\text { Better } \\
\text { parent }\end{array}$ & Ravaiyya \\
\hline $\mathrm{L} 1 \times \mathrm{T} 1$ & $54.65 * *$ & $24.08 * *$ & $43.29 * *$ & $29.54 * *$ & $15.08 *$ & 6.63 & $-20.92 * *$ & $-33.32 * *$ & $-25.72 * *$ \\
\hline $\mathrm{L} 1 \times \mathrm{T} 2$ & $28.53 * *$ & -1.46 & $29.01 * *$ & $18.06^{*}$ & -2.05 & 6.92 & $2.23^{* *}$ & 0.50 & $-23.16^{* *}$ \\
\hline $\mathrm{L} 1 \times \mathrm{T} 3$ & $49.86 * *$ & $36.55 * *$ & 15.94 & $19.30 *$ & $16.59 *$ & -16.09 & $-3.92 * *$ & $-20.56 * *$ & $-7.09 * *$ \\
\hline $\mathrm{L} 2 \times \mathrm{T} 2$ & $-13.53^{*}$ & $-29.42 * *$ & $46.08 * *$ & $-13.54 *$ & $-14.88 *$ & -3.44 & $-2.84 * *$ & $-7.78 * *$ & $-24.16^{* *}$ \\
\hline $\mathrm{L} 2 \times \mathrm{T} 3$ & $19.41 * *$ & $-15.80 *$ & $75.25 * *$ & $44.18 * *$ & $15.75^{*}$ & $31.30 * *$ & $-33.50 * *$ & $-43.37 * *$ & $-33.77 * *$ \\
\hline L3 $x$ T1 & $111.91 * *$ & $81.39 * *$ & $109.47 * *$ & $59.33 * *$ & $53.74 * *$ & $42.45 * *$ & $-4.63 * *$ & $-23.56 * *$ & $-14.84 * *$ \\
\hline $\mathrm{L} 3 \times \mathrm{T} 2$ & $91.82 * *$ & $56.14 * *$ & $104.42 * *$ & $54.23 * *$ & $37.98 * *$ & $50.62 * *$ & $15.72 * *$ & $10.49 * *$ & $-18.38 * *$ \\
\hline L3 $x$ T3 & $90.80 * *$ & $87.79 * *$ & $59.44 * *$ & $44.36^{* *}$ & $29.74 * *$ & 11.77 & $-36.51 * *$ & $-50.02 * *$ & $-41.54 * *$ \\
\hline $\mathrm{L} 5 \times \mathrm{T} 2$ & $63.32 * *$ & $38.45^{* *}$ & $81.26^{* *}$ & $46.68 * *$ & $35.62 * *$ & $48.05 * *$ & $13.00 * *$ & 0.34 & $-4.48 * *$ \\
\hline $\mathrm{L} 5 \times \mathrm{T} 3$ & $21.97 * *$ & $17.85 * *$ & 7.31 & $40.77 * *$ & $22.54 *$ & 13.60 & $-12.57 * *$ & $-20.70 * *$ & $-7.26 * *$ \\
\hline L6 x T1 & $-13.70 *$ & $-21.29 * *$ & 10.30 & -5.77 & $-24.47 * *$ & 16.04 & $-6.45 * *$ & $-12.37 * *$ & $-2.37 * *$ \\
\hline L6 x T2 & $65.98 * *$ & $60.52 * *$ & $124.94 * *$ & $34.47 * *$ & $15.00 *$ & $76.70 * *$ & $12.11 * *$ & $-1.39 * *$ & $-4.04 * *$ \\
\hline L6 x T3 & $47.51 * *$ & $18.45 * *$ & $65.98 * *$ & $27.62 * *$ & -7.66 & $41.87 * *$ & $-17.30 * *$ & $-24.24 * *$ & $-11.40 * *$ \\
\hline L7 x T1 & $83.11 * *$ & $75.48 * *$ & $102.64 * *$ & $75.07 * *$ & $51.49 * *$ & $92.12 * *$ & $11.14 * *$ & $-9.32 * *$ & $1.02 * *$ \\
\hline L7 x T2 & $38.74 * *$ & $25.45 * *$ & $64.25 * *$ & $57.35 * *$ & $46.45^{* *}$ & $85.74 * *$ & $37.12 * *$ & $33.89 * *$ & $-1.09 * *$ \\
\hline L7 x T3 & $67.01 * *$ & $50.48 * *$ & $59.29 * *$ & $95.04 * *$ & $50.25^{* *}$ & $90.55 * *$ & $-4.00 * *$ & $-23.11 * *$ & $-10.08 * *$ \\
\hline
\end{tabular}


More number of fruits per plant is a commercially important trait to gain high market value through high productivity. Most of the crosses had significant positive heterosis, heterobeltiosis and commercial heterosis over Ravaiyya. The range of average heterosis varied from $-13.54(\mathrm{~L} 2 \times \mathrm{T} 2)$ to $95.04 \%$ (L7 x T3). Nineteen crosses out of 21 registered significant positive average heterosis. For heterobeltiosis, the crosses ranged from -24.47 (L6 x T1) to $58.12 \%$ (L4 $x$ T3). Thirteen crosses exhibited significant positive commercial heterosis and ranged from -16.09 (L1 x T3) to $92.12 \%$ (L7 x T1) over Ravaiyya. Similar positive heterosis for this trait was reported by Sao and Mehta (2010) in brinjal.

The ultimate goal of any breeding programme is a maximization of marketable yield. The magnitude of heterosis ranged from -44.84 (L4 x T3) to $37.12 \%$ (L7 x T2), -50.43 (L4 x T3) to $33.89 \%(\mathrm{~L} 7 \times \mathrm{T} 2)$ and $-42.03(\mathrm{~L} 4 \mathrm{x}$ T3) to $1.02 \%$ (L7 x T1) over mid parent, better parent and commercial check respectively. Thirteen and fifteen hybrids showed significant positive heterosis over commercial check and better parent respectively for this trait. The positive heterosis for yield has been reported by Murthy et al., (2011) and Reddy and Patel (2014).The hybrid which exhibited highest heterosis for yield per plant among the different crosses in the present study was L7 $\mathrm{x}$ T1 (35.54).This cross also expressed significant positive commercial heterosis for number of primary branches, days to $50 \%$ flowering, fruit length and number of fruits per plant indicating that these quantitative traits might be contributed to high heterosis for fruit yield in brinjal.

Total phenols content of the fruit is one of the most important quality characters known to reduce the shoot and fruit borer incidence. If the total phenols content is high, borer infestation will be less (Kranthirekha, 2011). However from organoleptic point of view i.e., taste after cooking the total phenols content should be less in quantity. In the present study, the average heterosis for total phenols ranged from -44.84 (L4 x T3) to $37.12 \%$ (L7 $\mathrm{x}$ T2). The heterobeltiosis was lowest in L4 $\mathrm{x}$ T3 $(-50.43 \%)$ and it was highest in L7 x T2 ($33.89 \%)$. A total of seventeen crosses showed significant and negative heterobeltiosis. Of the twenty one crosses, twenty registered negative and significant commercial heterosis values with the range of -42.03 (L4 x T3) to 1.02 (L7 x T1). These results are in agreement with the findings of Makani et al., (2013).

\section{References}

Bhushan, B., Sidhu, A.S., Dhatt, A.S. and Ajay Kumar. 2012. Studies on combining ability for yield and quality traits in brinjal (Solanum melongena L.). Journal of Horticultural Science. 7(2):145-51.

Das, S., Mandal, A.B. and Hazra, P. 2009. Study of heterosis in brinjal (Solanum melongena L.) for yield attributing traits. Journal of Crop and Weed. 5(2): 25-30.

Kranthirekha G 2011. Evaluation of round fruited brinjal genotypes for yield, quality and tolerance to fruit and shoot borer. M. Sc. (Hort.) Thesis, Kerala Agricultural University, Thrissur. $133 \mathrm{pp}$.

Makani, A.Y., Patel. A.L., Bhatt, M.M. and Patel, P.C. 2013. Heterosis for yield and its contributing attributes in brinjal (Solanum melongena L.). The Bioscan. 8(4): 1369-71.

Murthy, S.R.K.R., Lingaiah, H.B., Naresh, P., Vinay Kumar Reddy, P. and Satish, K.V. 2011. Heterosis for yield and yield attributing characters in brinjal (Solanum melongena L.). Plant 
Archives. 11(2): 649-53.

Rai, M., Gupta, P.N. and Agarwal, R.C. 1995.

Catalogue on eggplant (Solanum

Melongena L.) germplasm Part -I.

National Bureau of Plant Genetic

Resources, Pusa Campus, New Delhi. pp. 1-3.

Rameshkumar, S., Arumugam, T., Anandakumar, C.R. and Rajavel, D.S. 2012. Estimation of heterosis and specific combining ability for yield, quality, pest and disease incidence in eggplant (Solanum melongena L.). Bulletin of Environment, Pharmacology and Life Sciences. 2 (1): 03-15.

Reddy, E.E.P. and Patel A.I. 2014. Heterosis studies for yield and yield attributing characters in Brinjal (Solanum melongena L.). Scholarly Journal of Agricultural Science. 4(2): 109-112.

Sao, A. and Mehta, N. 2010. Heterosis in relation to combining ability for yield and quality attributes in brinjal (Solanum melongena L.). Electronic Journal of Plant Breeding. 1(4): 783-88.

Suneetha, Y., Kathiria, K.B., Patel, J.S. and Srinivas, T. 2008. Studies on heterosis and combining ability in late summer brinjal. Indian Journal of Agricultural Research. 42(3): 171 -76.

Vavilov, N.I. 1931. The role of central Asia in the origin of cultivated plants. Bulletin of Applied Botany Genetics and Plant Breeding. 26(3): 3-44.

\section{How to cite this article:}

Sivakumar, V., K. Uma Jyothi, C. Venkataramana and Rajyalakshmi, R. 2017. Estimation of Heterosis for Yield and Yield Components in Brinjal (Solanum melongena L.) Over Locations. Int.J.Curr.Microbiol.App.Sci. 6(7): 1074-1081. doi: https://doi.org/10.20546/ijcmas.2017.607.129 